\title{
The War Comes Home: The Toll of War and the Shifting Burden of Care
}

Link to publication record in Manchester Research Explorer

\section{Citation for published version (APA):}

Howell, A., Wool, Z. H., Crawford, N. (Ed.), \& Lutz, C. (Ed.) (2011). The War Comes Home: The Toll of War and the Shifting Burden of Care. (The Costs of War). The Watson Institute for International and Public Affairs, Brown University. http://costsofwar.org/article/us-veterans-and-military-families

\section{Citing this paper}

Please note that where the full-text provided on Manchester Research Explorer is the Author Accepted Manuscript or Proof version this may differ from the final Published version. If citing, it is advised that you check and use the publisher's definitive version.

\section{General rights}

Copyright and moral rights for the publications made accessible in the Research Explorer are retained by the authors and/or other copyright owners and it is a condition of accessing publications that users recognise and abide by the legal requirements associated with these rights.

\section{Takedown policy}

If you believe that this document breaches copyright please refer to the University of Manchester's Takedown Procedures [http://man.ac.uk/04Y6Bo] or contact uml.scholarlycommunications@manchester.ac.uk providing relevant details, so we can investigate your claim.

\section{OPEN ACCESS}




\title{
The War Comes Home: The Toll of War and the Shifting Burden of Care
}

\author{
Alison Howell and Zoë H. Wool
}

Report after report and study after study begins by pointing out that the American military's post 9/11 engagements in Iraq and Afghanistan are taxing service members and their families like none before.

Lessons learned from draft era conflicts are of little use in understanding the full scale of the impact of these wars at home. For example, after the Cold War, the active duty force was reduced from 2.1 million to 1.4 million, ${ }^{1}$ thus requiring fewer service members and families to carry war's deadly burden and requiring longer and repeated deployments, especially in the Army and Marine Corp. American soldiers in Vietnam trying to survive the carnage of that killing field, and their families waiting at home, could count down a 365 day clock, knowing that if they survived that long, they wouldn't have to go back. That is not the case today.

The increasing pace of military operations necessitated by America's militarized response to $9 / 11$ - what is euphemistically referred to as OPTEMPO — is taking an unacceptable toll at home on both service members and their families. As General Chiarelli, Army Vice Chief of Staff, put it:

we now must face the unintended consequences of leading an expeditionary Army that included involuntary enlistment extensions, accelerated promotions, extended deployment rotations, reduced dwell time and potentially diverted focus from leading and caring for Soldiers in the post, camp and station environment. ${ }^{2}$

The summary of the 2009 National Leadership Summit on Military Families noted "There was consensus among participants that service members and their families are experiencing severe strain due to wartime deployments. The length and frequency of these deployments and lack of sufficient dwell time for recovery and reintegration has no parallel in the history of the modern all-volunteer force, or in the extent to which they tax Reserve component families." He also reported that "A number of participants strongly believed that policymakers should strive to reduce the length and frequency of deployments.",

The difficulty of military deployments always extends beyond the battlefield; when units deploy, local consumer economies suffer, families must adjust to life without loved ones and with the knowledge of the danger they may well be facing. When service members return, they may bring physical and emotional pain back with them, exacerbated by the new daily rhythms their families have had to forge in their absence. In addition to the more acute physical and emotional wounds service members must manage upon their return with uneven access to services, they face the challenge of readjusting to the rules, expectations, and pace of life at home and repositioning themselves in a social network that has shifted over the year or more they have spent in a war zone.

\footnotetext{
${ }^{1}$ Karney, Families under stress: an assessment of data, theory, and research on marriage and divorce in the military, iii.

${ }^{2}$ Chiarelli, Health Promotion, Risk Reduction, Suicide Prevention, iii.

${ }^{3}$ Booth, Wechsler Segal, and Bell, What We Know About Army Families: 2007 Update, 8.
} 
Families who have struggled to persevere — scrambling for childcare, rearranging work schedules, parents fearing for their children's lives or spouses trying to find social supports often in the absence of any family - must readjust to the presence of a loved one who may have been profoundly transformed by war and who may be unwilling or unable to explain that transformation. The honeymoon period that follows homecoming all too quickly gives way to frustration, fights, and the fracturing of intimate relationships.

The deployments necessitated by America's militarized response to 9/11 are not only dangerous, but also longer and more frequent than those of previous wars, all of which contributes to a potent homefront mix of tense family relationships, physical and emotional pain, and, increasingly, drug and alcohol abuse and other risky behavior that imperils the safety of life at home for both service members and their families. ${ }^{4}$ The consequence is to make military communities as a whole more precarious, meaning that service members - especially Soldiers and Marines who see the most combat - and civilian family members alike are subject to cycles of anxiety and trauma with outcomes like skyrocketing soldier suicide rates and child maltreatment when civilian spouses are unable to cope with the role of single parent in which such deployments cast them.

The effects of combat exposure, an increasingly common fact of life for service members in the post 9/11 era, are clear and lasting, impacting criminality, alcohol use, marriages, mental health, and overall life span. All of these effects are most pronounced in families that were already in precarious situations due to a wide array of socioeconomic and health related factors endemic to the largest, lowest ranking sectors of military communities (e.g. problems related to debt, financial illiteracy, alcohol and cigarette abuse all of which are linked to military service and exacerbated by combat deployment). ${ }^{5}$ In short, even when service members survive the immediate violence of combat, its lingering effects can still be dangerous, even deadly, for them and their communities at home.

\section{Homicide and Violent Crime}

There have long been concerns about the ways in which American service members who face the killing and dying of war might be broken by it and bring some form of it back with them, imperiling themselves and those around them at home

It was this scenario that The New York Times drew on in its 2008 series, War Torn, which described 121 murders committed by veterans of the wars in Iraq and Afghanistan. ${ }^{6}$ It is also this scenario that a 19 year old army wife draws on when she tells her mentally and physically war injured husband that he cannot keep a handgun in the house because he might wake up in the night, think he's in Iraq, and kill her or their son.

\footnotetext{
${ }^{4}$ Johnson et al., The Psychological Needs of U.S. Military Service Members and Their Families: A Preliminary Report.

${ }^{5}$ MacLean and Elder, "Military Service and the Life Course."; Johnson et al., The Psychological Needs of U.S. Military Service Members and Their Families: A Preliminary Report. Brown and Cushman, Compensation and Short-Term Credit Needs of U.S. Military Enlisted Personnel'; Chiarelli, Health Promotion, Risk Reduction, Suicide Prevention. Baker et al., "Trauma Exposure, Branch of Service, and Pysical Injury in Relation to Mental Health Among U.S. Veterans Returning from Iraq and Afghanistan." Institute of Medicine (U.S.) and Wedge, Combating tobacco use in military and veteran populations.

${ }^{6}$ Sontag and Alvarez, "War Torn."
} 
While available evidence does show that violence is up in military communities, ${ }^{7,8}$ especially in the Army, whose soldiers are most regularly exposed to protracted violence in the post 9/11 era, and among service members exposed to combat (including those without PTSD diagnoses), ${ }^{9,10}$ things are much more complicated than this image of the battle broken veteran running amuck would make it seem.

Since the invasion of Iraq in 2003, rates of violent crime such as rape, murder, aggravated assault, and aggravated sexual assault have been going up in the Army, with the steepest jump in 2007-2008. ${ }^{11}$ Sexual offences committed by active duty soldiers have tripled since the 2003 invasion of Iraq. ${ }^{12}$ Not including incidents dealt with through the Army's internal informal investigation procedures, ${ }^{13}$ there were 74,646 offences recorded in FY 2009. ${ }^{14}$

But this picture of criminality can too easily lend itself to a simplistic vilification of soldiers made monstrous, losing sight of the specific conditions of military life occasioned by the unsustainable pace and relentless violence of post 9/11 military engagements. To complicate the picture, think of this: 16,997 of the FY2009 sexual offences noted above were related to drug or alcohol abuse, something connected both to soldiers' own self medicating with illegal drugs and alcohol and also to the military's own attempts to medicate service members in order to manage their combat induced anxiety, depression, and pain: 1/3 of all soldiers take a prescribed medication and 14 percent of them are taking heavy duty prescription painkillers ${ }^{15}$, and vehicular mayhemincluding drunk driving and vehicular manslaughter-has risen 100 percent since $2004^{16}$.

But those soldiers struggling most acutely with their combat experiences whose suffering spills out into their communities do not just attempt to drink away their pain, lash out at loved ones, or compliantly pop pills. Rates of desertion (going AWOL, deserting, or missing movement) have more than doubled in the post $9 / 11$ era, increasing by 234 percent since $2004 .{ }^{17}$ The point is not to suggest that violent post $9 / 11$ deployments don't contribute to violence and crime at home. Both research and common sense say they do. Rather, the point is to make sure we keep in mind all the ways that the militarized response to 9/11 eats away at the lives of service members and their families and the fact that none of these can be clearly comprehended in isolation.

\footnotetext{
${ }^{7}$ Chiarelli, Health Promotion, Risk Reduction, Suicide Prevention.

${ }^{8}$ U.S. Army, Investigation of Homicides at Fort Carson, Colorado November 2008-May 2009.

9 Jakupcak et al., "Anger, hostility, and aggression among Iraq and Afghanistan War veterans reporting PTSD and subthreshold PTSD."

${ }^{10}$ Elbogen et al., "Correlates of anger and hostility in Iraq and Afghanistan war veterans."

${ }^{11}$ U.S. Army, Investigation of Homicides at Fort Carson, Colorado November 2008-May 2009.

${ }^{12}$ Chiarelli, Health Promotion, Risk Reduction, Suicide Prevention.

${ }^{13}$ These include investigations initiated under Army Regulation 15-6 which may or may not lead to formal charges and which need not include formal written complaints. The results of these investigations are only filed at the post where the investigation occurred and are not attached to soldiers' permanent records (unless they lead to formal charges or reprimand) or filed in any central database (Chiarelli, Health Promotion, Risk Reduction, Suicide Prevention, 47.). If cases dealt with under AR 15-6 investigations were included, these numbers would undoubtedly be higher.

${ }^{14}$ Ibid., ii.

${ }^{15}$ Chiarelli, Health Promotion, Risk Reduction, Suicide Prevention.

${ }^{16}$ Ibid., 72.

${ }^{17}$ Ibid.
} 


\section{The Case of Fort Carson and the Problem of Statistics}

In the summer of 2009 , media outlets around the country began reporting on a horrifying cluster of brutal murders and acts of violence, including suicide, committed by soldiers based at Ft. Carson in Colorado. Soldiers were killing and trying to kill strangers, girlfriends, each other, and themselves. Originally publicized by Dave Philipps at the Colorado Springs Gazette, ${ }^{18,19}$ the violence at Ft. Carson was a perfect storm of military violence come home to roost: Soldiers trained to kill and repeatedly exposed to some of the bloodiest fighting in Iraq, only to come home to inadequate or negligent mental health services, a macho attitude that stigmatized help seeking, and a command structure that turned a blind eye as they reproduced the intensity and violence of war at home, often though drug and alcohol fueled rages. All told, from 2005-2008, 14 soldiers at Ft. Carson were involved in 11 brutal homicides. One of them also killed himself. ${ }^{20}$

There are important lessons to be learned from the responses of both the military and the media to the events at Ft. Carson. While the media accounts sometimes moved in a sensationalist direction, unintentionally implying that all soldiers have been subjected to a kind of moral deprogramming that makes them both deadly and pitiable, the Army's response $^{21}$ made the issue individual background and behavior rather than the impact of military life and war experience, rooting the violence primarily in "a comprehensive list of individual predisposing factors, such as prior criminal behavior, drug or alcohol abuse," with "environmental factors" such as combat relegated to the background. ${ }^{22}$

A 2009 Army report found significant correlations between high intensity combat exposure and aggression, problematic alcohol use, criminal conviction, and significant other violence, ${ }^{23}$ and it repeatedly notes that the unit most of the soldiers were in had seen some of the most intense and bloody combat of the Iraq war. But the question of the impacts of combat exposure on any of these factors was essentially written out of the research since the data did not distinguish between instances of this risk increasing behavior before versus after combat. This allows the Army to focus on questions of overall 'resiliency' and to suggest programs and interventions that include combat experience as just one of a slew of risk factors that commanders and clinicians can watch for in individual soldiers. In its post hoc rush to pinpoint causes, this approach loses sight of the deadly context created by America's militarized response to 9/11.

Recent research with soldiers returning from Iraq and Afghanistan shows that soldiers exposed to violent combat, intense human trauma, or who kill another person are more likely to engage in a wide array of risky behaviors, including alcohol abuse and verbal and physical aggression, putting both themselves and those around them in danger. ${ }^{24,25}$ This research shows that it is precisely the violence of war that puts civilians

\footnotetext{
${ }^{18}$ Philipps, "Casualties of War, Patr I: The hell of war comes home."

${ }^{19}$ Philipps, "Casualties of War Part II: Warning Signs."

${ }^{20}$ U.S. Army, Investigation of Homicides at Fort Carson, Colorado November 2008-May 2009.

${ }^{21}$ This response included an 2008 epidemiological consultation and subsequent 2009 report on the factors that led to the violence.

${ }^{22}$ Garamone, "Officials unveil results of Fort Carson violent crime study."

${ }^{23}$ U.S. Army, Investigation of Homicides at Fort Carson, Colorado November 2008-May 2009, 12-13.

${ }^{24}$ Killgore et al., "Post-combat invincibility: Violent combat experiences are associated with increased risk-taking propensity

following deployment," 1119.
} 
and retuned service members at risk of violence at home, and that these lingering dangers are much more complicated, and much less spectacular, than the Ft. Carson murders would make things seem.

On the other hand, many media accounts of post-deployment violence that emphasize veterans' psychological problems like PTSD, as does The New York Times' War Torn series, may unintentionally make the same suggestion, while simultaneously tarnishing all combat veterans with the same tainted brush. For example, Rolling Stone's investigation of the events at Ft. Carson sensationalizes the violence there so much that readers can all to easily lose sight of the institutional facts they do include like that "a third of all staff positions in the behavioral-health unit at the post's medical center, Evans Army Community Hospital, were left unfilled in 2007, at a time when the base was experiencing an all-time high in PTSD cases."26

But what Dave Philipp's original account of the problems at Ft. Carson was intended to show, and what we can glean from the complex array of factors that various quantitative studies attempt to count, is that the exigencies of post 9/11 military life create a cascade of stress and trauma that subjects the homefront to the violence of war. While the military tries and fails again and again to create new and better programs and techniques to deal with problems as they see them-everything from new sections of the UCMJ to more harshly and swiftly punish substance abusers to better record keeping of incidents of Military Sexual Trauma - the record shows that these problems are a function of the militarized response to $9 / 11$ in all its complexity and totality - service members exposed to combat trauma and away from home too often, and for too long, civilian spouses scrambling to hold families together in their absence, these stresses and strains redoubled when deployments end and service members and the military look for quick fixes in drugs and alcohol which contribute to an array of violences in military communities, from drunk driving to suicide to domestic violence. The longer this militarized response continues, the worse the problems will get.

\section{Violence in Military Families}

Domestic violence has long been a concern in the military. Since 1999, Congress has been pushing the military to provide better resources and keep more reliable information about such violence. $^{27}$

Despite the fact that concern about violence in military families has only increased amid the pace of post 9/11 deployments, a 2010 Government Accountability Office report notes that the military has been both unwilling and unable to do what needs to be done when it comes to domestic violence in the military. The Department of Defense only agreed to three of seven GAO recommendations following a congressionally mandated 2006 report on the state of domestic violence in the military. In the 2010 follow-up report, the GAO stated that "DOD has addressed one of the recommendations in our 2006

\footnotetext{
25 Jakupcak et al., “Anger, hostility, and aggression among Iraq and Afghanistan War veterans reporting PTSD and subthreshold PTSD."

${ }^{26}$ Smith, "The Fort Carson Murder Spree."

27 10 U.S.C. $\$ 1562$
} 
report to improve its domestic violence program and taken steps toward implementing two more, but it has not taken any actions on four of the recommendations." 28

One of the fundamental failures of the DoD that the GAO points out is its inability to keep consistent or reliable track of incidents of violence in its own service communities. ${ }^{29}$ Because of this, it is hard to track the specific impact of the militarized response to 9/11 on violence in military homes and between members of military families, but the Army has noted that it's rates of domestic abuse have skyrocketed, increasing 177 percent since 2003. ${ }^{30}$

Research on the impact of deployment on military domestic violence rates in deployments characteristic of the pre 9/11 military has shown that deployment need not necessarily lead to increased rates of domestic violence when service members return home, ${ }^{31}$ but that the longer a deployment the more likely that it will. ${ }^{32}$ Given evidence that the transitions around deployment are especially difficult and cause spikes in spousal abuse rates, the repeated deployments required by post-9/11 OPTEMPO exacerbate these dangerous patterns. ${ }^{33}$ Again, the implication of this research is that the specific character of longer, more frequent, and more dangerous deployments in the post 9/11 era are especially dangerous for military communities.

In Army families with previously substantiated cases of child abuse, the deployment of a parent led to increased rates of child maltreatment. The impacts were greatest when civilian mothers in these families were left to care for their children alone, leading to three times the rate of child maltreatment, four times the rate of child neglect, and nearly double the rates of physical abuse as when soldier fathers were at home. ${ }^{34}$

Service members exposed to the trauma of combat may develop problems with substance and alcohol abuse as they seek to manage both the physical and emotional pain they continue to feel once they return. Because we know that heavy drinkers in the Army are 66 percent more likely to abuse their partners, ${ }^{35}$ and that alcohol abuse is a significant factor in suicides and other dangerous high risk behavior, it impossible to separate the increased exposure to war violence from the traumas in military families and communities: When service members exposed to the horrors of war attempt to manage their pain with alcohol or with all too readily available prescriptions, they imperil not only their own lives, but those of their family and community members.

Thus the scattered data on the impacts of the specific character of the 9/11 era deployments shows that the more often U.S. service members are away, and the more dangerous their deployments, the more likely it is that the violence of war will spill into the homefront in an array of forms, impacting spouses, children, and service members alike.

\footnotetext{
${ }^{28}$ U.S. Government Accountability Office and Farnell, Status of Implimentation of GAO's 2006 Recommendations on DOD's Domestic Violence Program, 4.

${ }^{29}$ U.S. Government Accountability Office and Farnell, Status of Implimentation of GAO's 2006 Recommendations on DOD's Domestic Violence Program.

${ }^{30}$ Chiarelli, Health Promotion, Risk Reduction, Suicide Prevention.

${ }^{31}$ McCarroll et al., "Domestic Violence and Deployment in US Army Soldiers."

${ }^{32}$ McCarroll et al., "Deployment and the Probability of Spousal Violence by U.S. Army Soldiers."

${ }^{33}$ Lutz, "Livingroom Terrorists."

${ }^{34}$ Gibbs et al., "Child Maltreatment in Enlisted Soldiers' Families During Combat-Related Deployments."

${ }^{35}$ Bell et al., "Drinking and Spouse Abuse among U.S. Army Soldiers."
} 


\section{Broader Impacts on Children}

Beyond legible and visible forms of violence and neglect in the homes of service member parents, the current shape of the military and the pace of deployments is having myriad negative effects on children. As of 2009, there were approximately 2 million American children with one or more parent in the military, and most of the children of active duty service members are seven years of age or younger. In 2007 there were 700,000 children who had least 1 parent on deployment ${ }^{36}$ and by 2008 there were more than 2 million American children who had a parent who either was deployed or had been deployed in Iraq and Afghanistan. ${ }^{37}$ Many have lost a parent, or have had a parent return home wounded. ${ }^{38}$ These children are disproportionately from minorities, and as many as 1 in 4 of them may be depressed. ${ }^{39}$ A 2010 military study also found that children are 11 percent more likely to utilize mental and behavioral health services, and to have 15 to 19 percent higher rates of disorders, when a parent is deployed ${ }^{40}$.

According to a recent survey of parents, child psychosocial morbidity among children of deployed service members was two and a half times the national average: 32 percent of children were classified as at 'high risk,' as compared to 18 percent in a peacetime survey of military families. A majority of parents reported that their children had trouble sleeping ${ }^{41}$ and many reported their children had problems at school, such as dropping grades, decreased interest and conflict with teachers. ${ }^{42}$ The problems these children experience at school are doubtless compounded by the frequent changes of school they experience as a result of their parent's service: as of 2009, the average military child could expect to have to changed school systems between six and nine times between kindergarten and $12^{\text {th }}$ grade. ${ }^{43}$ Amongst children of active duty service members, few attend Defense Department schools, while the majority attends public schools. ${ }^{44}$

\footnotetext{
${ }^{36}$ American Psychological Association, Presidential Task Force on Military Deployment Services for Youth, Families and Family Members. The Psychological Needs of U.S. Military Service Members and Their Families: A Preliminary Report. APA, February 2007.

http://www.apa.org/about/governance/council/policy/military-deployment-services.pdf. 4 .

37 Molinda M. Chartrand et al. 'Effect of Parents' Wartime Deployment on the Behavior of Young Children in Military Families'. Archives of Pediatric and Adolescent Medicine 162:11 (November 2008). 1009-1014.

${ }^{38}$ National Centre for Children in Poverty 'Trauma Faced by Children of Military Families: What Every Policymaker Should Know’ (New York: May 2010). http://www.nccp.org/publications/pdf/text_938.pdf.

${ }^{39}$ Eric M. Flake et al. 'The Psychosocial Effects of Deployment on Military Children.” Journal of Developmental and Behavioral Pediatrics 30:4 (August 2009). 271-278.

${ }^{40}$ Gorman, Eide, and Hisle-Gorman, "Wartime Military Deployment and Increased Pediatric Mental and Behavioral Health Complaints."

${ }^{41}$ Christopher Munsey, 'The Kids Aren't Alright' (report of American Psychological Association. Stress in America Survey 2009) Monitor on Psychology 41:1 (January 2010). 22. http://www.apa.org/monitor/2010/01/stress-kids.aspx.

${ }^{42}$ Eric M. Flake et al. 'The Psychosocial Effects of Deployment on Military Children.” Journal of Developmental and Behavioral Pediatrics 30:4 (August 2009). 271-278.

${ }^{43}$ Military Child Education Commission. A Legislator's Guide to Military Children (Harker, Texas: 2006). Vi. http://www.k12.wa.us/operationmilitarykids/pubdocs/MCECLegislatorsGuide.pdf.

${ }^{44}$ Department of Defense. 'Demographics 2009: A Profile of the Military Community." (Washington D.C.: 2010). http://cs.mhf.dod.mil/content/dav/mhf/QOL-

Library/PDF/MHF/QOL\%20Resources/Reports/2009_Demographics_Report.pdf.
} 
The war has had a serious impact on the mental health of the children of service members. According to the Marine Corps Times, outpatient mental health visits to children of service members doubled from 1 million to 2 million between 2003 and $2008 .^{45}$ In the same period, child psychiatric hospitalization for severe problems such as suicide attempts rose sharply. ${ }^{46}$ In general, longer parental deployment was associated with higher rates of mental health problems in children. A policy brief released by the National Centre for Children and Poverty in May 2010 reported that these problems are particularly attenuated amongst National Guard and Reserve service members who are called for duty, since they are less integrated into military social support networks. ${ }^{47}$ These problems are further compounded by the difficulty military families find in meeting their childcare needs. As of 2009, the military estimates that, even taking into account both military programs and civilian child care accessed by military families, there were 37,000 military children who needed but could not find child care spaces. ${ }^{48}$

\section{Suicide}

Suicide rates in the military are historically lower than those in comparable segments of the civilian population, in large part because the military recruitment process screens for the most significant forms of preexisting psychological dysfunction including depression. America's militarized response to $9 / 11$ has changed that, however. Since 9/11, the suicide rate among civilians the same age and gender as the military population has remained steady at around 18 (suicide rates are calculated as deaths per 100,000 people in the population). In 2002, suicide rates across the Department of Defense began increasing from a previously steady rate of around 10 per 100,000. According to the Armed Forces Medical Examiner, in 2003, the year of the invasion of Iraq, suicides across the DoD accounted for more deaths than combat. ${ }^{49}$ Despite suicide awareness campaigns across the services, across the DoD suicide outnumbered combat deaths again in $2008 .^{50}$ By 2009, DoD wide rates they were approaching 20 with numbers in the Marines and Army, who face the worst and most direct combat in post 9/11 deployments, surpassing even that threshold and outstripping civilian rates.

The Department of Defense knows that deployments are bad for mental health, that repeated deployments make it worse, and that "dwell time" between deployments is no solution. The 2010 Report of the Department of Defense Task Force on Suicide Prevention concluded that the number of forces is "not sufficient to meet operational

\footnotetext{
${ }^{45}$ Kimberly Hefling, 'More Military Children Seeking Mental Care.” Marine Corps Times July 7, 2009. http://www.marinecorpstimes.com/news/2009/07/ap_children_mental_health_070709/.

${ }^{46}$ Eric M. Flake et al. 'The Psychosocial Effects of Deployment on Military Children.” Journal of Developmental and Behavioral Pediatrics 30:4 (August 2009). 271-278.

47 National Centre for Children in Poverty 'Trauma Faced by Children of Military Families: What Every Policymaker Should Know' (New York: May 2010). http://www.nccp.org/publications/pdf/text_938.pdf.

${ }^{48}$ Presidential Report Strengthening Our Military Families: Meeting America's Commitment. (Washington D.C.: January 2011). 21.

http://www.defense.gov/home/features/2011/0111_initiative/Strengthening_our_Military_January_2011.pd f.

${ }^{\overline{4} 9}$ Chiarelli, Health Promotion, Risk Reduction, Suicide Prevention, 15.

${ }^{50}$ Ibid.
} 
requirements and maintain the well-being of the force." ${ }^{51}$ While the report suggests this is an issue of "supply and demand imbalance,",52 it is clear that if dwell time will not solve the problem, neither will increasing "supply" and exposing more Americans to the traumas of war. The only solution then, lies on the "demand" side.

Soldiers often describe the futility of participating in post-combat talk-therapy with councilors and therapists or chaplains who have not been to war, finding the gulf of understanding too broad and resenting the way in which well meaning counselors or therapists claim to understand what it is like. And research and policy recommendations that address PTSD consistently suggest that services are the most effective when provided within hours of traumatic events. The Army also knows that its lauded COIN doctrine which, among other things, brings troops off FOBs (Forward Operating Bases) and into the civilian population makes it harder to provide adequate care. As a 2008 Army press release noted "In Iraq, many soldiers were moved $[. .$.$] to small outposts where they could maintain close contact with Iraqi civilians$ and security forces. This placed them farther from care providers at large bases., ${ }^{23}$

One of the attempts to manage this irresolvable problem of COIN operations has been to send chaplains, who are largely responsible for providing mental health services in the Army, ${ }^{54}$ into the combat zone with service members. While this may give soldiers quicker access to their counsel, it imperils the lives of chaplains and can have unintended consequences. On Aug $30^{\text {th }}$ 2010, Capt. Dale Goetz became the first chaplain killed in combat since Vietnam. ${ }^{55}$ Pfc David Lawrence who saw Capt. Goetz as a friend and confidant cited his death as one of the factors that led to his depression and eventual mental breakdown during which he shot and killed an Afghan prisoner he was supposed to be guarding. ${ }^{56}$ What's more, the moral authority of chaplains, whose loyalties may be torn between their faith and their military mission, can be a charismatic force, glossing over soldier's moral and mental problems. When in 2003, profoundly disturbed after killing a civilian in Iraq, Army Calvery/Scout Garett Reppenhagen went to see his chaplain, he was told that "I did it for God and Country, that I'm in God's hands, I'm a kind of tool of God [and should] 'get our there and, you know, get back to work.",57

The alternative, and one that is receiving increasing support from military and civilian researchers alike, is to forget about the complexity of the picture and focus only on biological phenomena by treating war trauma with drugs or attempting to 'prevent' it by means of everything from playing the video game Tetris to monitoring biological markers of stress so as to push soldiers up to, but hopefully not past, a clinically identified breaking point. ${ }^{58,59}$ Soldiers would be exposed to the same kinds of violence and trauma but their brains would not manifest the patterns researchers have identified as problematic. The patterns they would manifest are anyone's guess. This research, which

\footnotetext{
51 Ibid., 73.

${ }^{52}$ Ibid.

${ }^{53}$ Harben, "Army Releases Mental Health Advisory Team V Report."

54 The use of chaplains is in tension with the fact that a 2010 Department of Defense survey found $25 \%$ of service members claimed no religious preference at all and with increased concern about the Christian sanctioning of violence in the Military (eg Sharlet, "Jesus Killed Mohammed: The crusade for a Christian military."; Lilley, "N. Zeland to remove Bible verses from sights.")

${ }^{55}$ Zucchino, "A chaplain's ultimate sacrifice for God and country."

${ }^{56}$ Perry, "Army private accused of murder in Afghan prisoner's death."

${ }^{57}$ Gutmann and Lutz, Breaking ranks : Iraq veterans speak out against the war, 132-133.

${ }^{58}$ Laney, "Tetris Blocks PTSD symptoms."

59 Steinberg and Kornguth, "Sustaining Performance Under Stress."
} 
focuses almost exclusively on PTSD - a diagnosis which is itself persistently hazysuggests a bleak future should the character of post 9/11 military deployments continue: the 'solutions' and 'cures' such research provides suggest legions of American men and women sent into combat and treated as little more than collections of bio-metric markers, subjected to brain scans, medication, and visual stimuli that keep their bio-chemical levels within predetermined ranges. ${ }^{60}$ While this might be a future without PTSD, it is one none of us can ethically condone.

While the rates of disorders such as PTSD (see below) may be a canary in the coal mine when it comes to the lasting impacts of war at home, the almost exclusive focus on PTSD as the cause of problems of suicide and other forms of violence in military communities is badly misplaced. Between 2005 and 2009, only 9 percent of soldiers who committed suicide had been diagnosed with PTSD and just over half ( 52 percent) had no behavioral health diagnosis at all. ${ }^{61}$

Indeed, the picture of military suicide is much more complicated than even a more general focus on mental health and illness would suggest. And as the 2010 Army report on suicide prevention rightly noted assumptions about a single clear and easily fixable relationship between combat connected mental disorders and suicide grossly underestimate the scale and complexity of the problem. ${ }^{62}$

A 2009 study looking at the San Diego VA system found that when the picture was expanded from PTSD to include depression, and clinical levels of substance and alcohol abuse, 64 percent of OEF/OIF veterans were suffering from clinical mental health problems, ${ }^{63}$ all of which increase suicide risk. The study also found that exposure to trauma and branch of service determined the likelihood of these diagnoses, rather than age, gender, race, or rank. ${ }^{64}$ Perhaps most insidiously, failed and failing intimate relationships are the most consistent factor in military suicides, implicated in 65 percent of suicides across the forces. ${ }^{65}$ This pattern provides a damning link between suicide and the many family strains caused by the breakneck speed of post 9/11 OPTEMPO.

A further dimension of the complexity of post $9 / 11$ military suicide is the way reserve component forces, on whom current deployments depend like never before, may feel the strains of combat more intensely than active duty components. For example, a JAMA study looking at the emergence of mental health issues in the months after Soldiers had returned from Iraq found that 42 percent of reservists needed mental health treatment, compared to 20 percent of active duty soldiers. And yet, across the forces, suicide rates among active duty troops across the forces are more than double than those in reserve components. ${ }^{66,67}$

\footnotetext{
${ }^{60}$ Military Psychology, Volume 21 Supplement 12009 sustaining Soldier High Operations Tempo

Performance

${ }^{61}$ Department of Defense Task Force on the Prevention of Suicide by Members of the Armed Forces, The Challange and the Promise: Strengthening the Force, Preventing Suicide and Saving Lives, 17.

${ }^{62}$ Chiarelli, Health Promotion, Risk Reduction, Suicide Prevention.

${ }^{63}$ Baker et al., "Trauma Exposure, Branch of Service, and Pysical Injury in Relation to Mental Health Among U.S. Veterans Returning from Iraq and Afghanistan."

${ }^{64}$ Ibid.

${ }^{65}$ Department of Defense Task Force on the Prevention of Suicide by Members of the Armed Forces, The Challange and the Promise: Strengthening the Force, Preventing Suicide and Saving Lives, 71.

${ }^{66}$ Ibid., 41.

${ }^{67}$ In 2009 the suicide rate in active duty forces was estimated to be 20.3 , while for reservists it was 8.6 (Ibid). The picture is different still when looking just at the Army: while active duty soldiers were over
} 
Emerging evidence also suggests that veterans are much more likely to commit suicide than the comparable general population, something military statistics and training do not and cannot address. Based on information from 2004-2007, male veterans were twice as likely as their civilian counterparts to commit suicide. ${ }^{68}$ For female veterans the risks were even worse; female veterans under 35 were more than three times as likely to commit suicide as their civilian counterparts. ${ }^{69}$

These patterns reflect the intensity and distribution of trauma as a consequence of America's militarized response to 9/11 as well as the failure of suicide prevention programs in place for years to stem the tied of needless deaths. It also points to the inability of researchers to pinpoint clear causes or predictors of suicide in the military, but this is not because of poor research; it is because the complexity of the problem is not reducible to isolable causes or quick fixes. Ten years on, one of the only things that is clear when it comes to suicide in the military is that rates among the forces most exposed to stress and violence by the 9/11 response are the highest and that the only way to ensure these rates go down is to stop such exposure.

\section{Divorce}

In 2005, USA Today, ${ }^{70}$ The Wall Street Journal, ${ }^{71}$ AP, ${ }^{72} \mathrm{NBC},{ }^{73}$ Fox, ${ }^{74}$ and others all reported on the increase in divorce rates among active duty military, steadily increasing in the post 9/11 era. The conventional wisdom was that military marriages were a casualty of increased deployments required by the military response to $9 / 11$. In 2007, the RAND cooperation carried out a meta-analysis that substantially complicated the picture of deployments that destroy marriages, finding that longer deployments did not lead to higher divorce rates. ${ }^{75}$ Even so, according to information from the Defense Manpower Data Center, "divorce rates have increased between 2001 and 2008 for all Active Duty populations (except Navy men), with increases being especially large for female Service Members" (Dr. Rachael Mapes, Special Assistant for Policy, Planning, and Evaluation in the Office of the Deputy Under Secretary of Defense for Plans, comments at the Leadership Summit on military Families in 2009). And the upshot of the RAND report was that deceptively straightforward metrics like divorce rates hide at least as much as they show.

\section{What Divorce Rates Show}

\footnotetext{
represented in Army suicides in 2009 (57\% of suicides, but only 40\% of the Total Army), evidence available in mid-2010 suggested that this would not be the case by year's end (Chiarelli, Health Promotion, Risk Reduction, Suicide Prevention, 18).

${ }^{68}$ Kaplan et al., "Suicide among male veterans: a prospective population-based study."

${ }^{69}$ McFarland, Kaplan, and Huguet, "Datapoints: self-inflicted deaths among women with U.S. Military service: a hidden epidemic?."

${ }^{70}$ Zoroya, "Soldiers' divorce rates up sharply; seperation, stress erodes marriages."

${ }^{71}$ Stout, "The Home Front: Time Out for Troubled Marriages."

${ }^{72}$ Crary, "As war-zone deployments increase, so does Army's divorce rate."

73 Potter, "The Homefront-Increased Divorce Rates."

${ }^{74}$ Foxnews.com "Army's Divorce Rate Increasing."

${ }^{75}$ Karney, Families under stress : an assessment of data, theory, and research on marriage and divorce in the military.
} 
Since we don't know what happens to service member marriages after they leave the service, it is impossible to figure the divorce rate as a percentage of all marriages that will eventually end in divorce. But we do know that the percentage of marriages that end in a given year has been steadily increasing in the military since 2000. This is true for both enlisted and officers and across all branches of the military. For example, in 2000, 1.4 percent of officer marriages and 2.9 percent of enlisted marriages ended in divorce while in 2009 , those numbers were 1.8 percent and 4.0 percent. ${ }^{76}$ Rates among Naval reserve officers have skyrocketed in the post 9/11 era, reaching 6.5 percent in $2009 .{ }^{77}$ Among people married to active duty military members, 54.3 percent are 30 or younger and half of all military spouses are not employed which means they are often dependant on their military spouses for both financial and social support. ${ }^{78}$

We know rates are increasing, and that enlisted personnel are both more likely to think about getting divorced and to actually get divorced then officers. ${ }^{79},{ }^{80} \mathrm{We}$ also know that female service members are less likely to be married but many times more likely to get divorced than male service members. ${ }^{81}$ But explaining changes in divorce rates, and attempting to find their causes is much more complicated. While the 2007 RAND metaanalysis cautions that absence of divorce is not necessarily proof of happy marriages, they also point to research that indicates exposure to combat, not just deployment, which is increasingly the case in the two post $9 / 11$ counterinsurgency wars the US military is currently waging, does correlate with marital problems. The RAND report also shows that the post 9/11 increased deployments tax segments of the service with new intensity-including the Reserves and National Guard as well as female service members. Because of this, husbands of service members and spouses of reserve component service members face new kinds of challenges and a lack of institutional resources to meet them, despite the fact that the 2006 federal budget was already requesting \$5.6 Billion for services for military families, a gargantuan amount which has not reversed the trend.

\section{...and What They Hide}

What divorce rates hide are the very thing they too often stand as proxy for: the manifold impacts of deployment on families left behind. For example, a 2010 study in the Journal of the American Association of Adolescent Psychiatry ${ }^{82}$ shows that while civilian spouses are themselves most distressed when their spouses are deployed, children of deployed parents show increased anxiety that does not dissipate when a deployed parent returns. The implication is that the damage done to families by deployment is cumulative, compounding, and lasting and is tractable in rates of anxiety: 25 percent of children of currently combat-deployed parents experienced anxiety, but the number was actually

\footnotetext{
${ }^{76}$ Office of the Deputy Under Secretary of Defense (Military Community and Family Policy),

Demographics 2009: Profile of a Military Community, 45.

${ }^{77}$ Ibid., 105.

${ }^{78}$ Ibid., 56-57.

${ }^{79}$ U.S. Army, Investigation of Homicides at Fort Carson, Colorado November 2008-May 2009.

${ }^{80}$ Karney, Families under stress : an assessment of data, theory, and research on marriage and divorce in the military.

${ }^{81}$ Ibid.

${ }^{82}$ Lester, "The Long War and Parental Combat Deployment."
} 
higher, 32 percent, for children whose parents had recently returned. ${ }^{83}$ A later section of this report details many of these in other quantifiable forms, like the rates at which spouses and children or deployed service require psychiatric care.

But it is not possible to convey in numbers the intense and constant fear that your spouse will be killed. Many service member spouses describe the dread that strikes them every time the phone rings, knowing that the voice on the other end could be the bearer of earth shattering news. Service members do not often discuss the horrors of war with their family members, sparing them full knowledge of them, but this also leads to silences that can strain the intimacy that may once have existed. But while such silences can help shield families from awful truths, these things that remain unsaid can be taxing on a relationship in their own ways and such 'protective' silence may contribute to service members' reluctance to seek help in dealing with war trauma. The alternative is not necessarily any better, since telling family members about combat experiences can be traumatic for them and add to their concern and fear for their absent partner or parent.

The picture of divorce and family stress - in clinical and military research and in the media - is one this one that focuses on spouses and children, but these strains are also felt by the deployed service members. For example, the longer a deployment the more likely service members are to think about their marriages ending. ${ }^{84}$ Soldiers often talk about the way they had to 'leave the family on the FOB' so that they wouldn't get "mindfucked" by thinking about their loved ones, rather than the deadly context around them. And while calls and emails home might be a small bright spot in the endless stretches of anxious boredom punctuated by combat, even the simplest questions of loved ones - "how are you" - put soldiers in ethical quicksand: tell the truth and burden your family with things you can only just bear, or lie about the things that cut you the deepest to the people you love the most.

\section{The Shifting Burden of Care for "Invisible Injuries"}

Given the ways in which the impacts of current deployments on families and in military communities are often rendered invisible, sometimes precisely by the kinds of metrics that seem to look for them, it is worth asking questions about who bears the burden of care for service members and looking especially deeply into the institutional cracks in which much of this work is made to hide.

Among service members themselves, mental health difficulties represent one of the major lasting effects of the high tempo and nature of the deployments that have formed the militarized response to $9 / 11$. In a way that is less visible, and perhaps more insidious than even the most endemic physical injuries and ailments that afflict returning service members, the burden of care associated with these mental health problems constitutes ones of the central effects when the war 'comes home.'

Accessing adequate, appropriate, and timely mental health care remains difficult for many returning service members and veterans. In 2007, the American Psychological Association reported that, after an extensive study, they were "not able to find any evidence of a well-coordinated or well disseminated approach to providing behavioral

\footnotetext{
${ }^{83}$ Ibid., 314-315.

${ }^{84}$ U.S. Army, Investigation of Homicides at Fort Carson, Colorado November 2008-May 2009.
} 
health care to service members and their families. ${ }^{\prime 85}$ In the ensuing years, several studies have shown that despite some improvements, fundamental gaps in the adequacy and quality of care, as well as institutional barriers to access to care remain. ${ }^{86}$ The purpose of this section, then, is to ask: Where does the responsibility go? Who bears the burden of care for armed services members experiencing difficulties as a result of their deployments?

It will illustrate how military policies and programs are increasingly working to off-load the burden of care for the mental health of service members - a burden created by the militarized response to $9 / 11$, and the decision to engage in counter-insurgency wars that place soldiers at higher risk of experiencing mental health difficulties. The burden of care has been shifted onto: armed forces members themselves; their peers; as well as civilians and civilian organizations, including families, especially wives, children, and by extension schools and communities. These groups are enlisted in doing unpaid work to take up the slack that results from the systemic inadequacy of care provided by the military and the VA. This spreading burden represents one of the significant external costs of the US response to $9 / 11$.

\section{Making Armed Forces Members Responsible: Individualizing Systemic Problems}

\section{The Politics of Diagnosis}

Members of the armed forces frequently get caught between either being denied appropriate mental health diagnoses, or being misdiagnosed: often for the purposes of denying their claims to medical and disability benefits. On the one hand, the difficulties with getting a diagnosis and treatment for PTSD are well-documented. The tendency to deny PTSD diagnosis in order to curb compensation claims, became especially controversial with the release of the 'Perez email': a communication sent in March 2008 by a PTSD program coordinator, stating that "Given that we are having more and more compensation seeking veterans, I'd like to suggest that you refrain from giving a diagnosis of PTSD straight out." Until recently, veterans were required to provide documentation showing that a particular event was at the root of their diagnosis before getting treatment, and it remains to be seen what effect recent changes will have. ${ }^{87}$ Additionally, in numerous cases armed forces members have been diagnosed with preexisting 'Personality Disorder' (PD): such diagnoses have been used to discharge soldiers without paying them disability or medical benefits. Since 2001, more than 22,600

\footnotetext{
${ }^{85}$ American Psychological Association, Presidential Task Force on Military Deployment Services for Youth, Families and Family Members. The Psychological Needs of U.S. Military Service Members and Their Families: A Preliminary Report. APA, February 2007. http://www.apa.org/about/governance/council/policy/military-deployment-services.pdf. 31 .

${ }^{86}$ See, for instance: Center for Military Health Policy Research, RAND Corporation. Invisible Wounds of War: Psychological and Cognitive Injuries, Their Consequences, and Services to Assist Recovery. Terri Tanielian and Lisa H. Jaycox, eds. April 2008. http://www.rand.org/content/dam/rand/pubs/monographs/2008/RAND_MG720.sum.pdf, see also M Audrey Burnam, Lisa S. Meredith, Terri Tanielian, and Lisa H. Jaycox. "Mental Health Care for Iraq and Afghanistan Veterans." Health Affairs. 28:3 (May/June 2009). 771-82.

${ }^{87}$ See Rachel Martin. "VA Eases Claims Process for PTSD Treatment." All Things Considered. NPR. January 12, 2010. http://www.npr.org/templates/story/story.php?storyId=128467680
} 
soldiers have been discharged with PD. ${ }^{88}$ Armed forces members have been retroactively diagnosed with a purportedly pre-existing personality disorder, despite the standard psychological screening that soldiers undergo upon enlisting. ${ }^{89}$ In these cases, because PD is deemed to be a pre-existing condition, the military is abdicated of responsibility for medical treatment, while those diagnosed with the disorder are then also denied access to disability pay, and may be made responsible for paying back a part of their enlistment bonus, often thousands of dollars. This process has relied on a diagnostic sleight of hand perpetrated with the aim of cutting costs: the diagnosis of PD has saved the Army at least $\$ 12.5$ billion to date. ${ }^{90}$ Little has been done to make military leadership accountable despite the protestations of a number of veterans organizations. ${ }^{91}$ Both the misapplication of the diagnosis of PD, and the frequent denial of the diagnosis of PTSD are indicative of a serious systemic problem that continues to persist: that of making members of the armed forces who have experienced mental, and in some cases accompanying physical injuries, responsible for their own care.

\section{The Trouble with Resilience and Prevention}

Military policies and programs have increasingly had to respond to pervasive mental health problems amongst members of the armed forces: but they have done so less by improving service provision than by turning to new models of resilience and mental fitness.

The 2010 Army Health Promotion, Risk Reduction, and Suicide Prevention ${ }^{92}$ report for example, praises the new Army Comprehensive Soldier Fitness program. In the program, soldiers are instructed in how to become resilient in the face of stressors. Members of the armed forces are inundated with messages about being responsible for their own stress reduction, mental fitness, and ability to grow rather than flounder in the face of traumatic events experienced during deployments. In military terms, prevention is seen as proactive, and therefore better than a 'reactive' response. While self-help and responsibility may carry positive meanings in civilian contexts, in military contexts policy shifts towards self-help, cognitive behaviour therapy or positive psychology pose a problem: when this kind of 'proactive' response is figured as an alternative to 'reactive' responses, medical, psychological and psychiatric care come to be treated as a negative outcome: treatment is reduced to being 'reactive,' and only necessary when services personnel fail to be responsible for their own mental states.

\footnotetext{
${ }^{88}$ Vietnam Veterans of America (VVA). Defense Department Wrongfully Discharges Nearly 26,000 Veterans, Refuses to Release Records. VVA, December 15, 2010. http://www.vva.org/PressReleases/2010/pr10-024.html. his neck, and causing him significant hearing loss, memory failure, and ultimately depression. He was deemed no longer combat-ready by 2006, but instead of discharging Town due to his injuries, doctors at Fort Carson, Colorado claimed that his wounds were caused by a 'personality disorder' that supposedly pre-dated his enlistment in the military. In the case of Spc. Town, this meant not only that he was denied medical and disability benefits, but also that he owed the Army $\$ 3000$ upon his discharge, as re-payment of his enlistment bonus.

${ }^{92}$ Available at: http://usarmy.vo.llnwd.net/e1/HPRRSP/HP-RR-SPReport2010_v00.pdf
} 


\section{Making Systemic Problems Appear Individual}

Like the mis-diagnosis of PD, and the failure in many cases to diagnose PTSD, preventive resilience and mental health programs work to make systemic problems appear individual. It is the individual soldier who is meant to be mentally fit and resilient. This is not simply a matter of equipping soldiers to deal with problems, but an attempt to place the responsibility for mental and physical injuries on the service members themselves. Preventive models that exhort armed forces members to be resilient are simply cheaper than the costs associated with providing adequate care. This costeffectiveness, however, shifts the burden of care onto service members themselves. It should be remembered that the military is a government employer: it would be unacceptable for any other government or major civilian employer to expose their workers to severely unsafe work conditions, and then respond by demanding that their employees seek self-help and resilience training, rather than provide compensation for injuries sustained on the job. At a minimum, the military should be held to these standards.

\section{Making Peers Responsible - 'Shoulder to Shoulder' in the Context of Inadequate Services}

In September 2010, the Army launched its Suicide Prevention Month with the theme of "Shoulder to Shoulder: I Will Never Quit on Life." In the words of one Colonel, "the theme promotes the dual responsibilities of suicide prevention - our pledge to be there for each other and our obligation to do everything we can to help ourselves... It's important to remember that while steps are being taken at all levels of the military to prevent suicides, the most effective level lies with individuals. It's imperative that we look out for each other."93 Grays words reflect the wider military approach to mental health: the demand for soldiers to self-care, outlined above, is coupled with a demand for their peers to be vigilant about the mental states of their fellow service members. In the words of one US Army Medical Department Behavioral Health poster: "Never let your buddy fight alone. Be willing to listen. Not all wounds are visible. Prevent suicide: It is your responsibility to get help for a fellow soldier." 94

Getting help for a fellow soldier, however, is a difficult task in the context of inadequate service provision. Making peers responsible for suicide prevention displaces the burden of mental health care provision from the military to armed forces members experiencing difficulties, and their peers.

\section{Making Families and Communities Responsible: Unpaid Work and Force Multiplication}

In the absence of adequate support and care for service members experiencing mental distress, one of the major costs of the war is to their families, to communities, and to civilian agencies and non-governmental organizations.

\footnotetext{
${ }^{93}$ Deborah Grays. 'Shoulder to Shoulder- I Will Never Quit on Life.” Fort McPherson, GA: September 15, 2010. http://www.army.mil/-news/2010/09/15/45189-shoulder-to-shoulder----i-will-never-quit-on-life/.

${ }^{94}$ Available at: http://www.armybase.us/wp-content/uploads/2009/07/suicide-prevention-poster-u.s.army.JPG
} 


\section{The Unbalanced Burden on Women}

Military policy is increasingly asking military families to be responsible for the care of returning soldiers, in effect, enlisting families, and especially spouses, as unpaid caregivers. Family members, in turn, pay with both their earning ability and their mental wellbeing.

This is a matter of intentional policy and programming: so, for example, in 2009 the DoD began an extensive strategic planning process to enhance 'family readiness programs. ${ }^{95}$ Families are systematically being called upon to do unpaid work in the name of supporting their loved ones, but for the express purpose of force multiplication: that is, rendering armed forces personnel fit for potential re-deployment. The military states that it is grateful for the service provided by families and communities, but it does not pay for this service, and amplifies the burden placed on families and communities by failing to provide adequate services. This voluntary, civilian, and informal service therefore represents a significant and often unrecognised external cost of the militarized response to 9/11 and the wars in Afghanistan and Iraq in particular.

It is a cost that is paid disproportionately by women. As of 2009, over 200,000 active duty service members were women, while over 1.2 million were men. More military men are married than military women. As a result, women comprise approximately 93 percent of spouses of active duty service members, and approximately 86 percent of spouses of reservists. ${ }^{96}$ When discussing the burden of the war for military spouses, we are therefore disproportionately discussing a burden borne by female spouses. When the military discusses the importance of 'family support' for returning soldiers, it is primarily asking for support from women. In effect, these women form an unpaid care workforce for the military. The work they do takes its toll, both emotionally and financially.

Their status as military spouses, involving as it does significant unpaid labor, as well as frequent involuntary relocations (approximately half of the spouses of active duty service members experienced a permanent relocation of their family as a result of their spouse's military commitments during 2007 and 2008 alone) has a significant impact on these wives' ability to earn a living. According to the most recent comprehensive study, conducted by the National Defence Research Institute study, the majority of military wives are employed. Nevertheless, even though they are, on average, younger, better educated and more likely to live in a metropolitan area than their civilian counterparts, they are less likely to be employed, and more likely to be seeking work, than civilian wives, and where they are employed, they are likely to be paid less than comparable civilian wives. ${ }^{97}$

\footnotetext{
95 Department of Defense. 'Plans for the Department of Defense for the Support of Military Family Readiness', Report to the Congressional Defense Committees. Washington D.C.: 2010. http://cs.mhf.dod.mil/content/dav/mhf/QOLLibrary/Project\%20Documents/MilitaryHOMEFRONT/Reports/2010\%20Report\%20to\%20Congress $\% 20$ NDAA $\% 20 \mathrm{Sec} \% 20581 . \mathrm{pdf}$

${ }^{96}$ Department of Defense. 'Demographics 2009: A Profile of the Military Community." (Washington D.C.: 2010). http://cs.mhf.dod.mil/content/dav/mhf/QOLLibrary/PDF/MHF/QOL\%20Resources/Reports/2009 Demographics_Report.pdf

${ }_{97}$ National Defense Research Institute. Working Around the Military: Challenges of Military Spouse Employment. (Rand Corporation: Santa Monica, 2004)
} 
The data regarding their mental health are more dramatic still. Based on data immediately following the onset of the wars in Afghanistan and Iraq, the New England Journal of Medicine ${ }^{98}$ reported that 37 percent of women with deployed husbands had at least one mental health diagnosis. ${ }^{99}$ Rates of depression were 24 percent among wives of deployed husbands, as compared to 9 percent among women nationally. ${ }^{100}$ Rates of disordered alcohol and drug use were nearly 50 percent higher among wives with husbands who had deployed, as compared to those whose husbands had not. All of these problems were significantly greater among wives of junior enlisted service members. ${ }^{101}$

Moreover, almost 50 percent of parents whose military spouses have deployed report 'clinically significant' parenting stress, and around a third report psychological problems in their children ${ }^{102}$. This stress is one of the major factors in diffusing psychological problems into children of deployed service members. This is a major issue, as the DoD admits, 'ongoing studies highlight the primarily negative impact of deployments on children. 103

The 2009 DoD Quadrennials Quality of Life Review states that "the Nation appreciates the sacrifices made by military members and their families" and "acknowledges the heightened importance of families, who also serve, particularly during times of war and heavy deployments." ${ }^{104}$ Families serve, however, in ways that are unpaid, and when such help is figured as a resource in military policy, it becomes a cost of the war that is intentionally transferred onto families.

\section{Shifting the Burden to Civilian Communities, Governmental and Non-Governmental Organizations}

Military planning seeks not only to use the unpaid labor provided by spouses who are most often female, but also by civilian communities, charities, and non-governmental organizations. For example, the 2009 DoD 'Plans for the Department of Defense for the Support of Military Family Readiness' report identifies the needs of reservists, and those living in civilian communities as particularly pressing, but places families and civilian resources as central assets to meet these needs. One of their recommendations is to 'harness community resources,' for example through the 'Network of Care' program that

\footnotetext{
98 Alyssa J. Mansfield et al. 'Deployment and the Use of Mental Health Services Among U.S. Army Wives.” New England Journal of Medicine 362:2 (January 14, 2010). 101-109.

${ }^{99}$ According to the National Institute of Mental Health. http://www.nimh.nih.gov/statistics/1ANYDIS_ADULT.shtml.

${ }^{100}$ According to the National Institute of Mental Health. http://www.nimh.nih.gov/statistics/1MDD_ADULT.shtml.

${ }^{101}$ Mansfield et al.

${ }^{102}$ Eric M. Flake et al. 'The Psychosocial Effects of Deployment on Military Children'. Journal of Developmental and Behavioral Pediatrics 30:4 (August 2009). 271-278.

${ }^{103}$ Department of Defense. 'Plans for the Department of Defense for the Support of Military Family Readiness', Report to the Congressional Defense Committees. Washington D.C.: 2010.

http://cs.mhf.dod.mil/content/dav/mhf/QOLLibrary/Project $\% 20$ Documents/MilitaryHOMEFRONT/Reports/2010\%20Report $\% 20$ to $\% 20$ Congress $\% 20$ NDAA $\% 20$ Sec $\% 20581 . p d f .8$.

${ }^{104}$ Department of Defense, 'Report of the Second Quadrennial Quality of Life Review'. Washington D.C.: January 2009. http://cs.mhf.dod.mil/content/dav/mhf/QOL-

Library/PDF/MHF/QOL\%20Resources/Reports/Quadrennial\%20Quality\%20of\%20Life\%20Review\%2020 09.pdf.
} 
works to locate local civilian support and resources for service members, veterans and their families, and through the 'Community Capacity Building' program that, according to the DoD seeks to "integrate existing resources provided by governmental and nongovernmental entities into a comprehensive and sustainable system of support for military families living in civilian communities." 105

The shifting of the burden of war onto civilians - whether families, communities, or the governmental, non-governmental and charitable sectors - is an express military policy. When the military seeks to enlist civilian services to provide the extra support necessitated by the war, it off-loads its responsibility to service members, their families, and their communities, and makes their support instrumental of broader military strategy. The costs of this support are made invisible in military budgets, making such support one of the hidden costs of the heavily militarized response to $9 / 11$.

${ }^{105}$ Department of Defense. 'Plans for the Department of Defense for the Support of Military Family Readiness', Report to the Congressional Defense Committees. Washington D.C.: 2010. http://cs.mhf.dod.mil/content/dav/mhf/QOLLibrary/Project $\% 20$ Documents/MilitaryHOMEFRONT/Reports/2010\%20Report $\% 20$ to $\% 20$ Congress $\% 20$ NDAA\%20Sec\%20581.pdf.11-12. 